DOI https://doi.org/10.30525v/978-9934-588-91-4-38

\title{
PHILOSOPHY OF MODERN POLITICAL CULTURE
}

\author{
Sakun A. V. \\ Doctor of Philosophy, \\ Associate Professor at the Department of Philosophy, \\ Political Science and Ukrainian Studies \\ Kyiv National University of Technology and Design \\ Kyiv, Ukraine \\ Kadlubovich T. I. \\ Candidate of Political Science, \\ Associate Professor at the Department of Philosophy, \\ Political Science and Ukrainian Studies \\ Kyiv National University of Technology and Design \\ Kyiv, Ukraine \\ Chernyak D. S. \\ Candidate of Sociological Sciences, \\ Associate Professor at the Department of Philosophy, \\ Political Science and Ukrainian Studies \\ Kyiv National University of Technology and Design \\ Kyiv, Ukraine
}

Political culture is one of the components of the spiritual and ideological subsystem of the political system of society. It is defined as a set of stable forms of political consciousness and behavior, as well as the nature and ways of functioning of political institutions within the political system [9, p. 480]. This is a «typical, integral characteristic of social actors and institutions, society as a whole, which fixes the level of development of their political consciousness, political activity and behavior» [7, p. 152].

Political culture determines «the degree of civilization of the political life of society» [7, p. 152], «is a measure of the political maturity of society and the state as a whole» [2, p. 83]. Therefore, the study and comprehensive analysis of this phenomenon is always relevant.

The philosophical aspect of the study of political culture involves its understanding as a multifaceted phenomenon of political life of society, which reflects the «range, dynamism and contradictions of the functioning of the political system» [8, p.364]. Therefore, political culture, according to modern researchers, includes not only the culture of political consciousness (values, traditions, customs, norms, ideas and beliefs, political guidelines), 
but also the culture of political structures, the culture of political activity and the culture of political relations.

Special attention should be payed to the culture of political relations. It is based primarily on the construction of political discourse, ie communication of a special ideal type, «meaningful» dialogue, the purpose of which is to critically discuss and justify the views and actions of participants, an instrument of knowledge and analysis of political reality (according to J. Habermas).

The culture of political relations implies tolerance in the perception of opinions and views of opponents, hostile and non-expansive attitude of one political entity to another, adherence to the principles of social and political consensus, the principle of equality of parties, dialogue between government and citizens. The desire for mutual understanding in discussing the most pressing issues eliminates domination and pressure, contributes to the consolidation of society.

Political relations should be an interaction, a communicative action that involves «subject-subject» interaction. Under such conditions, the communicator does not feel «higher» than the audience or recipient. Participants in political relations have equal rights and responsibilities, each of them does his job, expecting his partner to do his. At the same time, each of the subjects perceives itself as special and independent, becomes open to the other, respects its specificity. In this case, the subject not only associates himself with another, trying to understand his logic and values, fixing the areas of coincidence of goals and interests, but, at the same time, retains his own, unique «I», his freedom of choice and uniqueness of the spiritual world [6, p. 290]. The specificity of modern political relations is also due to the development of information technology, which leads to the fact that everyone seems to exist on their own, but is not isolated, «embedded in a complex and mobile, as never before» [4, p. 44], system of relations. "There is a virtualization of political space, the intertwining of reality with fictional events», and so on [3, p. 100-101]. Therefore, a person begins to treat such a reality skeptically and ironically. "Citizens' perceptions of politics are shaped by the means and images characteristic of the entertainment industry» [3, p. 101], and political culture acquires the characteristics of «culture of political entertainment» [3, p. 101]. A simplified, schematic view of politics is formed. «The postmodernist political culture is singled out, which focuses on the theatricalization of political life, hyperreality, consumption of symbols, fragmentation of life, distrust of the state, power, avoidance of real politics» [3, p. 102]. «The usual poles of attraction», writes Lyotard, «created by nation-states, parties, and historical traditions, are losing their appeal» [4, p. 43].

Policy implementation is a multidimensional process that takes place both vertically (from top to bottom and from bottom to top) and horizontally 
(between different actors, sectors of society and the economy). Recently, the role of the horizontal level of political relations is growing, the number of multidirectional vectors of political communication flows is increasing. Politicians «public» de jure, ie elected by the people, and «public» de facto, who head various power structures, enter the political arena [1, p. 5]. All of them take an active part in information exchange, perform in talk shows, are present on social networks, etc., while demonstrating the level of their own political culture. Society demands from politicians a high level of political culture, namely: professionalism, ability to resolve conflicts, dialogue, find compromises, be responsible, be able to answer to others, keep promises.

Unfortunately, the modern political culture of Ukrainian society requires improvement and development, as the traditions of authoritarian rule have not yet died out, and a single strategy for reforming the political system has not been formed. There is a lack of mutual understanding between different political actors, and political actors are unwilling to engage in dialogue and cooperation, have a low level of professionalism and a general culture. As a result, the low level of political culture allows for bureaucracy and corruption, manipulation of public opinion and mistrust among political actors.

These disadvantages of political life can be corrected by developing a common direction of change, improving self-organization skills, raising the level of political education, providing opportunities for self-development and self-realization of the individual as a subject of political relations.

\section{References:}

1. Груша А. В. Формы и методы организации взаимодействия субъектов политики. Пресса и политический диалог : учебное пособие. M., 2001. $23 \mathrm{c}$.

2. Жеребятнікова I. В. Проблеми трансформації рівня политичної культури в сучасному українському соціумі. Філософія $i$ політологія 6 контексті сучасної культури. 2013. Вип. 6(1). С. 83-88. URL: http://nbuv.gov.ua/UJRN/filipol_2013_6\%281\%29_19

3. Ирхин Ю.В. Политическая культура: современные методы анализа. Социально-гуманитарные знания. 2016. № 3. С. 93-107. URL: https://cyberleninka.ru/article/n/politicheskaya-kultura-sovremennyeproblemy-analiza

4. Лиотар Ж.-Ф. Состояние постмодерна / Пер. с фр. Н.А. Шматко М.,; Спб., 1998. 160 с.

5. Правова і політична культура українського соціуму за умов модернізації політико-правового життя : монографія / [О. О. Безрук, Л. М. Герасіна, І. В. Головко та ін.]; за ред. М. П. Требіна. Харків, 2016. 560 с.

6. Стризое А. Л. Политика и общество: социально-философские аспекты взаимодействия. Волгоград, 1999. 340 с. 
7. Сучасна політична лексика : енциклопед. словник-довідник / [I. Я. Вдовичин, Л. Я. Угрин, Г. В. Шипунов та ін.]; за наук. ред. Хоми Н. М. Львів, 2015. 396 с.

8. Філософія: Навчальний посібник / І. Ф. Надольний, В. П. Андрущенко, І. В. Бойченко, В. П. Розумний та ін.; За ред. І. Ф. Надольного. Київ, 1997. 584 с.

9. Шляхтун П. П. Політологія (теорія і історія політичної науки). Київ, 2002.576 с.

DOI https://doi.org/10.30525/978-9934-588-91-4-39

\title{
МІСЦЕ УКРАЇНИ В СУЧАСНІЙ СИСТЕМІ СВРОПЕЙСЬКОЇ БЕЗПЕКИ
}

\author{
Тімкін І. Ф. \\ кандидат історичних наук, доцент, \\ доцент кафедри соиіальних технологій факультету лінгвістики та \\ соиіальних комунікацій \\ Національного авіаційного університету \\ м. Київ, Украӥна \\ Новікова Н. С. \\ старший викладач кафедри сочіальних технологій факультету \\ лінгвістики та сочіальних комунікацій \\ Національного авіаційного університету \\ м. Київ, Украӥна
}

Нова геополітична ситуація у світі характеризується протистоянням ключових суб'єктів системи європейської безпеки (з одного боку США, НАТО та ЄС, з іншого-Росії).

3 часу створення $\mathrm{CC}$ західні держави гальмували розвиток його оборонних ресурсів, які формально передбачені в установчих договоpax. Європа залишилась у стані стратегічної військово-політичної та військово-технологічної залежності від НАТО і США. Асиметрія американо-європейських політичних можливостей очевидна і у НАТО, де США забезпечує три чверті витрат. Станом на 2013 рік витрати на оборону в державах Свропи у порівнняні за періоди першої половини 90-х років загалом скоротилися з 2,5 до 1,6 \% ВВП. Зазначені тенденції призвели до ситуації, коли європейці не здатні себе захистити від військової агресії [1]. 